$1988,37,2$

удК 57.083 .13

R. TENNO, K. TIISMA, T. PAALME and R. VILU

\title{
STOCHASTIC CONTROL OF GROWTH IN FED-BATCH CULTURE OF BACTERIA
}

\author{
(Presented by E. Lippmaa)
}

Using the stoichiometric equation of growth and Monod type kinetic equation, a deterministic model of growth of microorganisms in fed-batch culture was built. A stochastic model of the process was developed on the basis of the deterministic description. A stochastic control algorithm which is using filtered data was developed.

\section{Introduction}

Interest to the computer-aided fermentations could be traced back to the sixties [1]. The first persons to point out the possibility of computer monitoring of indirectly measured parameters were Yamashita, Hoshi, and Inagaki in $1969{ }^{[2}$. The idea has been implemented in several papers $\left[{ }^{3-9}\right]$, where methodological and experimental problems of computer monitoring of fermentations, using indirectly measured parameters, have been investigated. Much less attention has been paid to the problems of parameter identification, using Kalman filter or other filtering schemes [10-11]. Realizations of on-line control algorithms, published, could be divided into three classes: a) control through monitoring and regulation of a certain parameter (RQ, etc) at specific value, which ensures the achievement of the formulated aim of the control $\left[{ }^{4}, 12,13\right]$, b) control on the basis of a deterministic kinetic process model [7, $\left.{ }^{74-17}\right]$, and c) recently a stochastic control algorithm of fermentation processes was published [18].

A stochastic control algorithm which is using filtered data for partly observable fed-batch cultivation process of microorganisms was built in the present paper.

\section{Results and discussion}

2.1. A deterministic model of growth of microorganisms

Aerobic growth of microorganisms is described by a stoichiometric equation

$$
\begin{aligned}
& x_{1} \underset{\text { substrate }}{\mathrm{C}_{a} \mathrm{H}_{b} \mathrm{~N}_{c} \mathrm{O}_{d}}+x_{2} \mathrm{O}_{2}+x_{3} \mathrm{NH}_{3}= \\
& =x_{4} \underset{\text { biomass }}{\mathrm{C}_{e} \mathrm{H}_{f} \mathrm{~N}_{g} \mathrm{O}_{h}}+x_{5} \mathrm{CO}_{2}+x_{6} \mathrm{H}_{2} \mathrm{O}+x_{7} \mathrm{C}_{i} \mathrm{H}_{j} \mathrm{~N}_{k} \mathrm{O}_{l}
\end{aligned}
$$

in which $x_{1}, \ldots, x_{7}$ are stoichiometric coefficients (not necessarily constant). Use of ammonia as nitrogen source does not restrict the generality of the equation. In eq. (1) we have taken into account only the four major elements comprising more than $95 \%$ of biomass - carbon, hydrogen, nitrogen and oxygen. Minor elements - phosphorus, sulphur, potassium, etc. as well as variability of stoichiometric coefficients will be taken into 
account as uncontrolled disturbances in stochastic model of the growth process.

Stoichiometric coefficients obey elemental balance equations

$$
\mathbf{A X}=0 \text {, }
$$

where

$$
\mathbf{A}=\left[\begin{array}{rrrrrrr}
a & 0 & 0 & -e & -1 & 0 & -i \\
b & 0 & 3 & -f & 0 & -2 & -j \\
c & 0 & 1 & -g & 0 & 0 & -k \\
d & 2 & 0 & -h & -2 & -1 & -l
\end{array}\right], \quad \mathbf{X}=\left[\begin{array}{c}
x_{1} \\
\vdots \\
\vdots \\
x_{7}
\end{array}\right]
$$

It follows from eq. (1) that

$$
Q_{1} / x_{1}=Q_{2} / x_{2}=Q_{3} / x_{3}=Q_{4} / x_{4}=Q_{5} / x_{5}=\dot{Q}_{6} / x_{6}=\dot{Q}_{7} / x_{7},
$$

where $\dot{Q}_{i}=d Q_{i}(t) / d t, i=1,2, \ldots, 7$ is production or consumption rate of the corresponding components: $Q_{1}$ - growth substrate, $Q_{2}$ - oxygen, $Q_{3}$ - ammonia, $Q_{4}$ - biomass, $Q_{5}$ - carbon dioxide, $Q_{6}-$ water, and $Q_{7}$ - products, synthesized during the cultivation. It should be noted that all the parameters used throughout this work except elements of matrix $\mathbf{A}$ and constants $c_{0}, c_{1}, \ldots, c_{6}$, together with $\sigma_{1}, \sigma_{2}, r_{2}, r_{3}$, introduced below, are functions of time. However, designation of the functional dependence is removed from the equations, and preserved only in the cases where emphasizing of the functional dependence is considered especially important.

The system of equations (2) has (7-rank A) $>3$ nontrivial solutions. Let us assume rank $\mathbf{A}=4$, which is correct in most cases of growth. Let us define vectors

$$
\mathbf{Z}^{\mathrm{T}}=\left(x_{4}, x_{6}, x_{7}\right), \quad \mathbf{Y}^{\mathrm{T}}=\left(x_{1}, x_{2}, x_{3}, x_{5}\right)
$$

and matrices $\mathbf{B}$ and $\mathbf{C}$ according to equation

$$
\mathrm{AX}=\mathrm{BY}+\mathbf{C Z} \text {. }
$$

If matrix $\mathbf{B}$ is positively defined, then fundamental solution of eq. (2) is determined by

$$
\mathbf{Y}=-\mathbf{B}^{-1} \mathbf{C Z}
$$

or

where

$$
x_{i}=-\sum_{j=4,6,7} q_{i j} x_{j}, \quad i=1,2,3,5 \text {, }
$$

From eq. (3) and (4) it follows that

where

$$
Q_{i}=\mu_{i} \dot{Q}_{4}, \quad i=1,2,3,5,
$$

$$
\mu_{i}=-\left[q_{i 4}+q_{i 6} \dot{Q}_{6} / \dot{Q}_{4}+q_{i 7} \dot{Q}_{7} / \dot{Q}_{4}\right]^{+1} .
$$

Biomass $Q_{4}$, products $Q_{7}$ and water $Q_{6}$ formed (cf. eq. (1)) change in the fermentor according to (bounded) exponential law

where

$$
Q_{4}=F Q_{4}, \quad Q_{6}=c_{4} Q_{4}, \quad Q_{7}=c_{5} Q_{4},
$$

$$
F=c_{0} Q /\left[V+c_{1} Q+c_{2} Q^{2} / V+c_{3} Q_{7}\right]
$$

is a Monod (type) function taking into account growth inhibition by substrate and by products, and $Q / V$ is concentration of unutilized growth substrate in fermentor

$$
Q=\alpha-Q_{1},
$$


$\alpha$ is added (controlled) and $Q_{1}$ - utilized amount of growth substrate, $V$ is the current culture volume

$$
V=c_{6} \alpha,
$$

and $c_{0}, \ldots, c_{6}-$ constants. In our case (see also $\left[{ }^{19}\right]$ ):

$$
\begin{array}{lll}
c_{0}=40 \mathrm{mM}^{-1} \mathrm{~h}^{-1}, & c_{1}=100 \mathrm{mM}^{-1}, & c_{2}=10 \mathrm{mM}^{-1}, \\
c_{3}=100 \mathrm{mM}^{-1}, & c_{4}=0.4 \mathrm{~h}^{-1}, & c_{5}=0,1 \mathrm{~h}^{-1} .
\end{array}
$$

It is derived from equations (6), (7) that

$$
\mu_{i}=-\left[q_{i 4}+\left(\left(c_{4} q_{i 6}+c_{5} q_{i 7}\right) / F\right)\right]^{+1}, \quad i=1,2,3,5 .
$$

Eq. (5) and (9) together with eq. (7) and (8) form a system of nonlinear equations the solution of which is $\left(\mu_{i}, F\right)\left(t, V, Q_{1}, Q_{4}\right)$. Through integration by parts of (5):

$$
\begin{aligned}
& Q_{1}=\tilde{Q}_{1}-\tilde{\mu}_{1} \tilde{Q}_{4}-\int_{0}^{t} Q_{4} \dot{\mu}_{1} d \tau+\mu_{1} Q_{4}, \\
& Q_{4}=\tilde{Q}_{4}-\tilde{Q}_{5} / \tilde{\mu}_{5}+\int_{0}^{t}\left[\dot{\mu}_{5} /\left(\mu_{5}\right)^{2}\right] Q_{5} d \tau+Q_{5} / \mu_{5},
\end{aligned}
$$

where « denotes the initial conditions, and « $\cdot »$, as usually, are time derivatives, we obtain extended system (5), (7) - (10) the solution of which is $\left(\mu_{i}, F\right)\left(t, V, Q_{5}(\cdot)\right)$. These functions will be used below in constructing the stochastic model of the growth process and in nonlinear filtering of the data. It should be noted here that it is known from the experimental investigations that the functions $\mu_{1}(\cdot)$ and $\mu_{5}(\cdot)$ for a particular organism do not vary considerably. Usually the range for $\mu_{1}=2 \ldots 3$ and for $\mu_{5}=0,2 \ldots 0,5$. This fact simplifies essentially the calculation of the functions.

In the cases when $F$ and $\mu_{i}$ could be considered constants, at least approximately, the calculations described by eq. (5), (7)-(10) are essentially simplified.

\subsection{Stochastic model of the growth of microorganisms}

Deterministic model does not take into account uncontrolled factors (peculiarities of physiological state of the cells depending on the characteristics of inoculum, deviations from homogeneity in fermentor, etc) which cause batch-to-batch variations of the growth process $\left[{ }^{10}\right]$. Beside these 'intrinsic' to the growth process stochastic factors, the errors of the measurements should be also taken into account. These considerations lead to the construction of the stochastic model of the growth. The simplest stochastic model of the growth process is obtained in the case when $\left\{Q_{5}(t)\right\}$ is an observable process. Let us define the following model for the growth biomass:

$$
d Q_{4}=F\left(t, V, Q_{5}\right) Q_{4} \mathrm{dt}+\sigma_{4} d w_{4},
$$

for the amount of consumed growth substrate:

$$
d Q_{1}=\mu_{1}\left(t, V, Q_{5}\right) d Q_{4}+\sigma_{1} d w_{1},
$$

and for the measurement procedures:

$$
d \xi_{i}=\mu_{i}\left(t, V, Q_{5}\right) d Q_{4}+r_{i} d w_{i}, \quad i=2,3 .
$$

Here $\mathbf{w}=\left(w_{1}, w_{4}, w_{2}, w_{3}\right)^{\mathrm{T}}$ and $\left(\mathbf{w}_{t}\right)$ is a standard Wiener process, $\sigma_{1}$, $\sigma_{4}$ - constants which characterize the noise of the process of substrate consumption and biomass growth, respectively, and $r_{i}, i=2,3$ - mean square deviations of the measurements errors. 
If the process $\left\{Q_{5}(t)\right\}$ is observed with low noise (low observation error), the real values of $Q_{5}$ could be replaced in equations (8)-(10) by observed values $\xi_{5}$, and an additional equation is added to the system

$$
d \xi_{5}=\mu_{i}\left(t, V, \xi_{5}\right) d Q_{4}+r_{5} d w_{5} .
$$

Proposed replacement does not complicate the filtering problem. However, if $\left\{Q_{5}(t)\right\}$ is measured with high level of noise (great observation error), then the filtering problem is much more complicated, it has infinite dimensions.

\subsection{Filtering}

From the analysis of the stochastic model of the growth process, equations (11)-(14), it follows that for each $t$ conditional mean $\mathbf{m}_{t}=$ $=M\left(\mathbf{Q}_{t} / \xi_{[0, t]}\right)$ and conditional covariation $\mathbf{H}_{t}=\operatorname{Cov}\left(\mathbf{Q}_{t} / \xi_{[0, t]}\right)$ of the unobserved vector $\mathbf{Q}_{t}=\left(Q_{4}(t), Q_{1}(t)\right)^{\mathrm{T}}$ are calculated from equations

$$
\begin{aligned}
d \mathbf{m} & =\mathbf{a m d t}+\mathbf{G}\left(\mathbf{B B}^{\mathrm{T}}+\mathbf{R}\right)^{-1}(d \xi-\mathbf{A m d t}), \\
\mathbf{H} & =\mathbf{a} \mathbf{H}+\mathbf{H a}^{\mathrm{T}}+\mathbf{b} \mathbf{b}^{\mathrm{T}}-\mathbf{G}\left(\mathbf{B B}^{\mathrm{T}}+\mathbf{R}\right)^{-1} \mathbf{G}^{\mathrm{T}},
\end{aligned}
$$

where

$$
\begin{aligned}
& \mathbf{a}=F\left[\begin{array}{ll}
1 & 0 \\
\mu_{1} & 0
\end{array}\right], \quad \mathbf{b}=\left[\begin{array}{cc}
\sigma_{4} & 0 \\
\mu_{1} \sigma_{4} & \sigma_{1}
\end{array}\right], \quad \mathbf{A}=F\left[\begin{array}{l}
\mu \\
0
\end{array}\right]^{\mathrm{T}}, \\
& \mathbf{B}=\left(\sigma_{4} \mu, 0\right), \quad \mathbf{G}=\mathbf{b B}^{\mathrm{T}}+\mathbf{H} \mathbf{A}^{\mathrm{T}}, \\
& \mu=\left(\mu_{i}\right), \quad \xi=(\xi i), \quad i=2,3,5 \text { and } \\
& \mathbf{R}=\left(r_{i}^{2}\right)-\text { diagonal matrix. }
\end{aligned}
$$

If one of the parameters $\xi_{2}$ or $\xi_{3}$ is not measured in the experiment, the calculations could be carried out according to equations (15) after excluding the appropriate coordinates of vectors $\mu$ and $\xi$, and also the appropriate row and line from matrix $\mathbf{R}$.

\subsection{Control algorithm}

In many important, from the practical point of view, cases of cultivation of microorganisms, the aim of the control is to maximize the amount of biomass synthesized from the beginning of cultivation. It follows from eq. (8) that the formulated aim is approximately achieved if the amount of unutilized growth substance increases slowly according to equation

$$
Q(t)=\left\{V_{t} / c_{2}\left[V_{t}+c_{3} Q_{7}(t)\right]\right\}^{1 / 2},
$$

i. e. if the control is given by an approximate nonlinear equation

$$
\alpha(t) \approx Q_{1}(t)+\left\{\left(V_{t} / c_{2}\right)\left[V_{t}+c_{3} c_{5} \int_{0}^{t} Q_{4}(\tau) d \tau\right]\right\}^{1 / 2} .
$$

In the framework of the stochastic approach the simplest aim of the control is maximization of a mean value of the amount of biomass $M\left\{Q_{4}(t) / \xi_{[0, t]}\right\}$ synthesized from the beginning of cultivation. The aim is approximately achieved by the control:

$$
\alpha(t)=m_{1}(t)+\left\{\left(V_{t} / c_{2}\right)\left[V_{t}+c_{3} c_{5} \int_{0}^{t} m_{4}(\tau) d \tau\right]\right\}^{1 / 2},
$$

where $\mathbf{m}_{t}=\left(m_{4}(t), m_{1}(t)\right)^{\mathrm{T}}$ is the solution of filtering eq. (15). It could be shown that the proposed (separated) control (17) is admissible in the sense that the system of eq. (14) has unique strong solution $\left[{ }^{20}\right]$, and there exists the feedback control from the observations. 
1. Nyiri, L. K. In: Advances in Biochemical Engineering (eds T. K: Ghose, A. Fiechter,

N. Blakebrough). Berlin-Heidelberg-New York, Springer Verlag, 1972, 49-95.

2. Yamashita, S., Hoshi, H., Inagaki, T. In: Fermentation Advances (ed. D. Perlman.) New York, Academic Press, 1969, 441-463.

3. Cooney, C. L., Wang, H. Y., Daniel, I. C. Biotechnol. Bioeng., 19, 55-67 (1977).

4. Wang, H. Y., Cooney, C. L., Wang, D. I. C. Biotechnol. Bioeng., 19, $69-86$ (1977).

5. Bravard, J. B., Cordonnier, M., Kernevez, J. P., Lebeault, J. M. Biotechnol. Bioeng., 21, $1239-1249$ (1979).

6. Swartz, J. R., Cooney, C. L. Biotechnol. Bioeng. Symp., 9, 95-101 (1979).

7. Wang, H. Y. Cooney, C. L. Biotechnol. Bioeng., 21, 975-995 (1979).

8. Mou, D.-G., Cooney, C. L. Biotechnol. Bioeng., 25, 225-255 (1983).

9. Mou, D. G., Cooney, C. L. Biotechnol. Bioeng., 25, 257-269 (1983).

10. Leigh, J. R., Man Hee $\mathrm{Ng}$. In: Lecture Notes in Control and Information Sciences. Analysis and Optimization of Systems (eds A. V. Balakrishnan, M. Thoma). Berlin-Heidelberg-New York-Tokyo, Springer Verlag, 1984, 456-467.

11. Kotob, S., Albrech, C., Juraidan, M., Kafeety, H. In: Proc. of 10th IFAC Congress. Munich, 1987, 344-349.

12. Hampel, W., Woehrer, W., Bach, H. P., Roehr, M. Acta Biotechnol., 2(4), 331-336 (1982).

13. Johnson, A. In: Proc. of 10th IFAC Congress. Munich, 1987, 362-367.

14. D'Ans, G. Kokotovic, P. V., Gottlieb, D. IEEE Trans. Autom. Control, AC-16(4), $341-347$ (1971).

15. Haemaelaeinen, R. P., Halme, A. Automatica, 12(5), 400-415 (1976).

16. Humphrey, A. E., Zabriskie, D. W., Armiger, W. B., Ziegler, W. M. ACS Symp. Ser. Computer Applications in Chemical Engineering, 124, 355-366 (1980).

17. Holmberg, A. Acta Polytech. Scand., 33, 3-46 (1981)

18. Rolf, M. J., Lim, H. C. Biotechnol. Bioeng., 27, 1236-1245 (1985).

19. Pirt, S. J., Principles of Microbe and Cell Cultivation. Oxford-London-EdinburghMelbourne, Blackwell Scientific Publications, 1975.

20. Liptser, R. S., Shiryayev, A. N. Statistics of Random Processes. New York, Springer Verlag, 1977.

Academy on Sciences of the Estonian SSR, Institute of Cybernetics

Received March 4, 1987

Academy on Sciences of the Estonian SSR,

Institute of Chemical Physics and Biophysics

R. TENNO, K. TIISMA, T. PAALME, R. VILU

\section{BAKTERITE KASVU STOHHASTILISE JUHTIMISE ALGORITM NENDE KULTIVEERIMISEKS FED-BATCH-REZIIMIS}

Kasutades kasvu stöhhiomeetrilist võrrandit ning Monod' laadi kineetika võrrandit on loodud deterministlik mudel, mis kirjeldab bakterikultuuri kasvu fed-batch-režiimis. Kasvu stohhastiline mudel on loodud deterministliku mudeli alusel. Väljaarendatud stohhastilise juhtimise algoritm fed-batch-kultiveerimisrežiimi jaoks põhineb deterministlikul juhtimisseadusel, kus tundmatud suurused on asendatud filtreeritud kaudsete mõōtmistulemustega.

\section{Р. ТЕННО, К. ТИНСМА, Т. ПААЛМЕ, Р. ВИЛУ}

\section{АЛГОРИТМ СТОХАСТИЧЕСКОГО УПРАВЛЕНИЯ РОСТОМ БАКТЕРИИ В РЕЖИМЕ ПЕРИОДИЧЕСКОГО КУЛЬТИВИРОВАНИЯ С ПОДПИТКОИ}

С использованием стехиометрического уравнения роста и уравнения Моно построена детерминистическая модель роста бактериальной культуры в режиме периодического культивирования с подпиткой и положена в основу соответствующей стохастической модели. Алгоритм стохастического управления реализует детерминистический закон управления путем замены неизвестных параметров отфильтрованными данными косвенных измерений. 